\title{
SVEIKATOS PRIEŽIŪROS SPECIALISTŲ, DIRBANČIŲ BENDROJO POBŪDŽIO LIGONINÉSE, POŽIŪRIS İ DARBO APLINKOS VEIKSNIUS
}

\author{
Tomas Steponkus, Rūta Ustinavičienė, Gvidas Urbonas \\ Lietuvos sveikatos mokslu universiteto Visuomenes sveikatos fakultetas
}

Raktažodžiai: sveikatos priežiūros specialistai, darbo aplinka, bendrojo pobūdžio ligoninès.

\section{Santrauka}

Darbo aplinka plačiai nagrinèjama mokslo literatūroje, tačiau trūksta mokslinių tyrimų, skirtų pačių darbuotojų darbo aplinkos vertinimui ir ypač specifinèmis darbo sąlygomis išsiskiriančiame sveikatos priežiūros sektoriuje.

Tyrimo tikslas. Ištirti sveikatos priežiūros specialistų, dirbančių bendrojo pobūdžio ligoninèse, požiūrị ị darbo aplinką ir sąsajas su sociodemografiniais veiksniais. Tyrimo medžiaga ir metodika. Tyrime naudota anketiné apklausa - subjektyvaus darbo aplinkos vertinimo klausimynas, siekiant nustatyti sveikatos priežiūros specialistų požiūrị ị darbo aplinkos veiksnius. Tyrime dalyvavo 636 sveikatos priežiūros specialistai. Duomenų analizei buvo taikomi aprašomosios statistikos ir chi kvadrato $\left(\chi^{2}\right)$ ir z kriterijaus metodai bei Phi arba Cramer's V koreliacijos koeficientai. Rezultatai. Respondentų nuomone, jų darbo aplinkoje nepalankiai veikia biologiniai (55,7 proc.), cheminiai (50,8 proc.), ergonominiai ( 44,8 proc.) ir fiziniai (43,1 proc.) darbo aplinkos veiksniai. Dažniausiai respondentų buvo minimos dezinfekcinès medžiagos (48,0 proc.), žmogaus kūno skysčiai (47,5 proc.) ir biologinès atliekos (36,0 proc.). Moterys dažniau nurodo nepalankius cheminius, fizinius bei ergonominius darbo aplinkos veiksnius negu vyrai $(\mathrm{p}<0,05)$. Slaugytojų padejejjai ir slaugytojos nurodo daugiau ergonominių veiksnių, lyginant su gydytojais ar kitais specialistais $(\mathrm{p}<0,05)$. Išvados. Cheminiai ir biologiniai darbo aplinkos veiksniai veikia daugiau negu pusę respondentų. Moterys dažniau nepalankiai vertino fizinès, cheminès ir ergonominès darbo aplinkos veiksnius. Nustatytos sąsajos tarp lyties, pareigu ir fizinès, ergonominès ir cheminès darbo aplinkos vertinimo bei naktinio darbo ir cheminès ir biologinès darbo aplinkos vertinimo.

\section{Ivadas}

Sveikatos priežiūros darbuotojų darbo sąlygos yra specifinès (pavyzdžiui, darbas pamainomis (naktimis), pacientu kilnojimas, stresas ir pan.). Jų darbo aplinkoje gausu sveikatai kenksmingų veiksnių. Globalioje darbo rinkoje sveikų ir darbuotojams palankių darbo sąlygų užtikrinimas gali būti viena iš veiksmingiausių priemonių darbdaviui išlaikyti kvalifikuotą darbo jègą, o valstybei - sumažinti ,,protų nutekejjimą" bei patiriamas ekonomines išlaidas [1]. Auganti Lietuvos gyventojų emigracija, įskaitant tokią kvalifikuotą darbo jègą, kaip sveikatos priežiūros specialistai bei dideli jų darbo krūviai, verčia ieškoti tokios elgsenos motyvų. Mokslinejje emigraciją nagrinėjančioje literatūroje, taip pat viešojoje erdvejje vis dažniau minima šio reiškinio priežastis - darbo sąlygos [2-4]. Palanki darbo aplinka skatina darbuotojus pasilikti savo darbovieteje, o dideli darbo krūviai susiję su mažu slaugytojų ketinimu pasilikti esamame darbe. Ivairių tyrimų rezultatai palaiko sveikos darbo aplinkos kūrimą, kurią galima sukurti taikant subalansuotą darbo krūvị ir tinkamą darbo aplinką $[5,6]$. Darbo aplinka veikia ne tik darbuotojus, bet ir pacientų pasitenkinimą jų sveikatos priežiūra. Pavyzdžiui, pacientai, hospitalizuoti padaliniuose, kur slaugytojų darbo aplinka buvo vertinama gerai, buvo labiau patenkinti suteiktomis paslaugomis [7, 8]. Darbuotojų darbo aplinka yra susijusi ir su jų darbo efektyvumu [9]. Dirbantys su cheminiais, ergonominiais, biologiniais, fizikiniais ir psichosocialiniais veiksniais dažniau nurodè ịvairius sveikatos stiprinimo veiklu poreikius, lyginant su darbuotojais, kurie šių veiksnių riziką patiria retai [10].

Darbo tikslas - ištirti sveikatos priežiūros specialistų, dirbančių bendrojo pobūdžio ligoninèse, požiūrị ị darbo aplinkos veiksnius ir sąsajas su sociodemografiniais veiksniais. 


\section{Tyrimo medžiaga ir metodai}

Tyrimas buvo vykdomas $2018 \mathrm{~m}$. 5-iose Lietuvos bendrojo pobūdžio ligoninèse ( 2 regioninès, 2 rajoninès ir 1 respublikinè), kurio metu sveikatos priežiūros specialistams buvo tiesiogiai išdalintos 742 anketos, siekiant ịvertinti darbuotojų požiūrị ị darbo aplinką (1 lentelè). Atmetus ne visiškai užpildytas, sugadintas ar klausimynų tyrimo metodikų netenkinančias anketas (106), duomenų analizei buvo atrinktos 636 kokybiškai užpildytos anketos (atsako dažnis 85,7 proc.).

Didžioji dalis respondentų buvo 41-60 metų amžiaus (65,3 proc.), jauniausia respondentų grupe $18-25 \mathrm{~m}$. sudare 4,1 proc., vyriausia (61 ir daugiau metu) amžiaus grupe sudarè 15,1 proc. nuo visų apklaustujųu. Daugiausia tyrimo da-

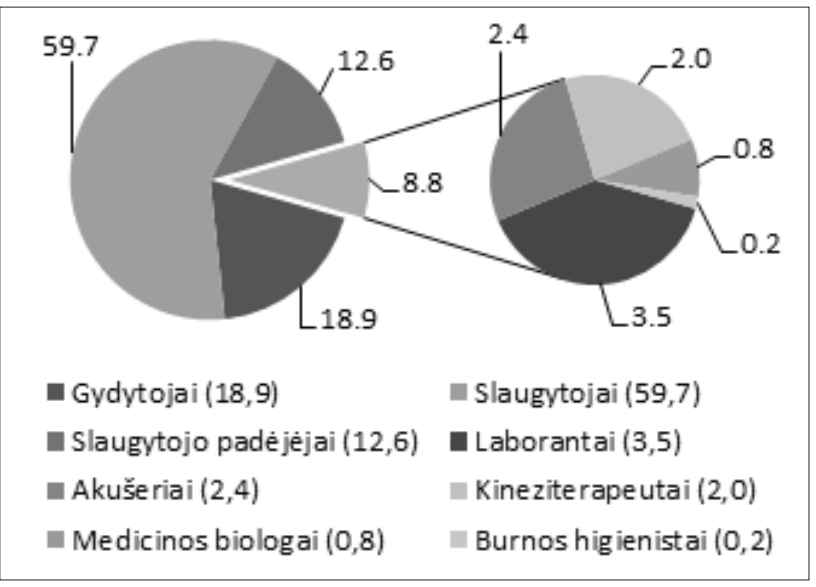

1 pav. Sveikatos priežiūros specialistų skirstinys pagal pareigas (proc.).

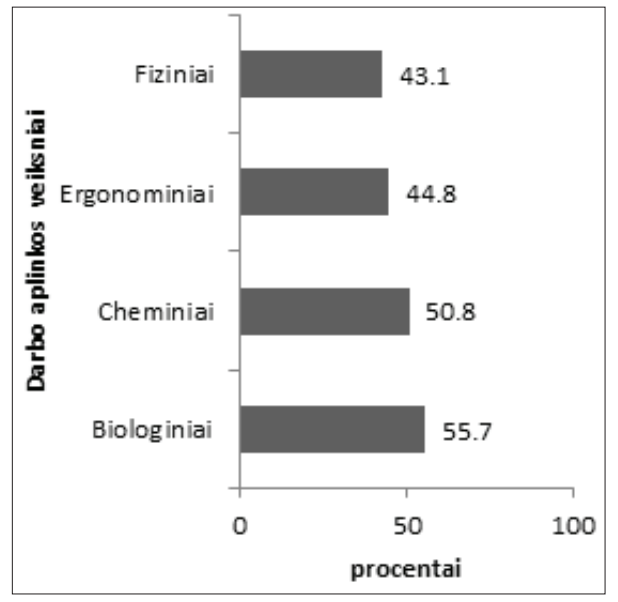

2 pav. Sveikatos priežiūros specialistų nepalankios darbo aplinkos veiksnių vertinimas. lyvių turèjo aukštesnijji (39,6 proc.) ir aukštaji universitetini (27,7 proc.) išsilavinimą.

Didžiają daugumą tyrime dalyvavusių respondentų sudare slaugytojai, slaugytojų padejejai ir kiti specialistai (1 pav.).

Respondentų apklausai naudotas subjektyvus darbo aplinkos vertinimo klausimynas siekiant nustatyti sveikatos priežiūros specialistų požiūrị ị darbo aplinkos veiksnius. Jame pateikiami labiausiai tiketini cheminiai, ergonominiai, biologiniai ir fiziniai veiksniai, su kuriais gali susidurti sveikatos priežiūros specialistai ligoninès darbo aplinkoje [11-13].

Tyrimui atlikti buvo gautas Kauno regioninio biomedicininių tyrimu etikos komiteto leidimas Nr. BE-2-55.

Duomenu analizei taikytas chi kvadrato $\left(\chi^{2}\right)$ ir z kriterijus (siekiant patikrinti hipotezę apie kintamujų suderinamumą) ir Phi arba Cramer's V koreliacijos koeficientai (ryšio stiprumui tarp kintamųų nustatymui). Rodiklių skirtumai laikomi statistiškai reikšmingais, kai $p<0,05$ (pasirinktas statistinio reikšmingumo lygmuo 95 proc.). Tyrimo duomenys buvo analizuojami naudojant ,MS Excel“" ir SPSS 22.0 programas.

\section{Rezultatai}

Nustatyta, kad tyrime dalyvavę Lietuvos bendrojo pobūdžio ligoninèse dirbantys sveikatos priežiūros specialistai dažniausiai susidūrè su biologiniais, rečiausiai - fiziniais darbo aplinkos veiksniais. Vertinant ligoninių pobūdį nebuvo nustatyta statistiškai reikšmingo skirtumo tarp jų ir sveikatos priežiūros specialistų subjektyvaus darbo aplinkos veiksnių vertinimo ( 2 pav.).

Moterys dažniau nurode fizinius, cheminius ir ergonominius darbo aplinkos veiksnius nei vyrai. Vertinant skirtumus tarp darbo aplinkos vertinimo ir pareigų, nustatyta, kad

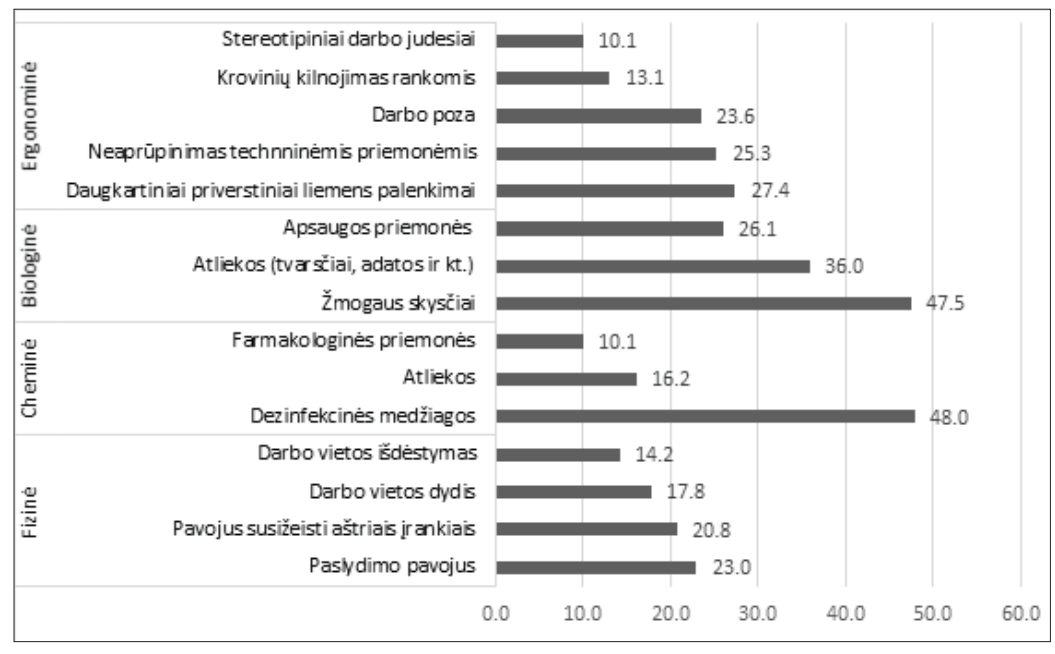

3 pav. Dažniausios su darbo aplinka susijusios rizikos, su kuriomis susidūrè $>10$ proc. respondentų (proc.). 
slaugytojai ar slaugytojų padèjejjai dažniau skundèsi fizinès ir ergonominès darbo aplinkos veiksniais nei gydytojai ir kiti specialistai. Gydytojų darbo aplinkoje rečiau pasitaikẻ cheminių darbo aplinkos veiksnių negu slaugytojų ar slaugytojų padejejęu bei kitų specialistų. Dažniau su ergonominiais veiksniais susidūre slaugytojo padejejajai ir slaugytojai negu gydytojai ar kiti specialistai (2 lentelè). Atlikus ergonominès darbo aplinkos veiksnių ir pareigų ryšio analizę, nustatytas statistiškai reikšmingas ryšys tarp minètų veiksnių ir pareigų: krovinių tvarkymą rankomis slaugytojai (15,0 proc.) ir slaugytojo padejejjai (27,5 proc.) nurodè dažniau negu gydytojai (1,7 proc.) ir kiti sveikatos priežiūros specialistai (3,6 proc.) $(p<0,001)$. Slaugytojų padèjèjai (37,5 proc.), slaugytojai $(32,6$ proc.) ir kiti sveikatos priežiūros specialistai $(23,2$ proc.) dèl priverstinių liemens palenkimų skundèsi dažniau negu gydytojai $(5,8$ proc.) $(p<0,001)$.

Tiriant su kokiais nepalankiais veiksniais darbo aplinkoje susidūrè specialistai, nustatyta, kad beveik pusè respondentų cheminių veiksnių šaltinius nurodė naudojamas dezinfekcines medžiagas. Beveik kas antras tyrimo dalyvis kontaktuoja su žmogaus kūno skysčiais ar jais užterštais paviršiais, mažesnè dalis dalyvių skundèsi dẻl biologinėmis medžiagomis užterštų atliekų (pvz., tvarsčiais, adatomis), saugos prie- monių (pvz., pirštinès, respiratoriai ir kt.). Vertinant fizinės darbo aplinkos veiksnius sveikatos priežiūros specialistai pažymėjo, kad dažniausiai susidūrè su paslydimo, kritimo ar griuvimo esant nelygiam, slidžiam ar šlapiam pagrindui pavojumi ir pavojumi susižeisti aštriomis įrankių dalimis. Gaisro (2,5 proc.) ar elektros (6,0 proc.) sukeltą pavojų nurode tik maža dalis sveikatos priežiūros specialistų (3 pav.).

Šio tyrimo duomenys taip pat rodo, kad dirbantys naktimis dažniau susidūrè su nepalankiais cheminiais ir biologiniais veiksniais (2 lentelè). Dezinfekcinès medžiagos kèlè problemas dažniau dirbantiems naktị $(51,6$ proc.) $(p<0,001)$. Atliekas (tvarsčius, adatas ir kt.), kaip sukeliančius nepalankią biologinę darbo aplinką, dažniau nurodè dirbantys naktị ( 41,7 proc.), negu nedirbantys naktị ( 23,5 proc.) $(p<0,001)$. Respondentai, dirbantys naktimis, nepalankių ergonominių veiksnių šaltinį nurodẻ kaip nepakankamą ar netinkamą aprūpinimą techninėmis priemonėmis (pvz., keltuvais, patogiomis kẻdemis ir pan. (28,7 proc.), negu nedirbantys naktinio darbo (18 proc.). Dirbantys naktimis dažniau skundèsi dẻl daugkartinių priverstinių liemens palenkimų (30,7 proc.), nepakankamu ar netinkamu aprūpinimu techninemis priemonėmis (pvz., keltuvais, patogiomis kèdėmis) (28,7 proc.), krovinių tvarkymo rankomis $(15,1$ proc.). Dirbantys naktimis

\begin{tabular}{|l|l|}
\hline Rodikliai & $\begin{array}{l}\text { Rezultatai } \\
\text { N (proc.) }\end{array}$ \\
\hline Lytis & \\
\hline Moterys & $571(89,4)$ \\
\hline Vyrai & $68(10,6)$ \\
\hline Ligoninės & \\
\hline Rajoninè $(\mathrm{N}=2)$ & $201(31,5)$ \\
\hline Regioninė $(\mathrm{N}=2)$ & $203(31,6)$ \\
\hline Respublikinè $(\mathrm{N}=1)$ & $235(36,8)$ \\
\hline Pareigos & \\
\hline $\begin{array}{l}\text { Gydytojas } \\
\text { Slaugytojas } \\
\text { Slaugytojo padejèjas } \\
\text { Kiti sv. pr. specialistai }\end{array}$ & $\begin{array}{l}120(32,5) \\
80(12,6) \\
56(8,8)\end{array}$ \\
\hline $\begin{array}{l}\text { Darbo pobūdis } \\
\text { Dirba naktimis } \\
\text { Nedirba naktimis }\end{array}$ & $\begin{array}{l}438(68,5) \\
201(31,5)\end{array}$ \\
\hline
\end{tabular}

1 lentelè. Respondentų sociodemografinès charakteristikos.

\begin{tabular}{|c|c|c|c|c|c|c|c|c|c|}
\hline \multirow{3}{*}{\multicolumn{2}{|c|}{ Kintamieji }} & \multicolumn{8}{|c|}{ Darbo aplinka } \\
\hline & & \multicolumn{2}{|c|}{ Fizinè } & \multicolumn{2}{|c|}{ Ergonominè } & \multicolumn{2}{|c|}{ Cheminè } & \multicolumn{2}{|c|}{ Biologinè } \\
\hline & & $\begin{array}{c}\mathrm{N} \\
\text { (proc.) }\end{array}$ & $\begin{array}{l}\text { Ryšio } \\
\text { stiprumo }\end{array}$ & $\begin{array}{c}\mathrm{N} \\
\text { (proc.) }\end{array}$ & $\begin{array}{l}\text { Ryšio } \\
\text { stipru- }\end{array}$ & $\begin{array}{c}\mathrm{N} \\
\text { (proc.) }\end{array}$ & $\begin{array}{c}\text { Ryšio } \\
\text { stiprumo }\end{array}$ & $\stackrel{\mathrm{N}}{\text { (proc.) }}$ & $\begin{array}{c}\text { Ryšio } \\
\text { stiprumo }\end{array}$ \\
\hline \multirow{3}{*}{ Lytis } & Moterys & & \multirow{3}{*}{$0,137^{* *}$} & 265 & \multirow{3}{*}{$0,107^{* *}$} & & \multirow{3}{*}{$\underset{*}{0,148^{*}}$} & & \multirow{3}{*}{0,05} \\
\hline & & $(45,4)^{* *}$ & & $(46,7)^{*}$ & & $(53,3)^{* *}$ & & $(56,5)$ & \\
\hline & Vyrai & $\begin{array}{c}16 \\
(23,5)^{* *}\end{array}$ & & $\begin{array}{c}20 \\
(29,4)^{*}\end{array}$ & & $\begin{array}{c}20 \\
(29,4)^{* *}\end{array}$ & & $\begin{array}{c}33 \\
(48,5)\end{array}$ & \\
\hline \multirow{3}{*}{$\begin{array}{l}\text { Ligo- } \\
\text { ninè }\end{array}$} & $\begin{array}{l}\text { Rajoni- } \\
\text { né } \\
(\mathrm{N}=2)\end{array}$ & $\begin{array}{c}86 \\
(42,8)\end{array}$ & \multirow{3}{*}{0,11} & $\begin{array}{c}86 \\
(42,8)\end{array}$ & \multirow{3}{*}{0,35} & $\begin{array}{c}100 \\
(49,8)\end{array}$ & \multirow{3}{*}{0,2} & $\begin{array}{c}101 \\
(50,2)\end{array}$ & \multirow{3}{*}{0,09} \\
\hline & $\begin{array}{l}\text { Regioni- } \\
\text { né } \\
(\mathrm{N}=2)\end{array}$ & $\begin{array}{c}89 \\
(43,8)\end{array}$ & & $\begin{array}{c}90 \\
(44,3)\end{array}$ & & $\begin{array}{c}106 \\
(52,2)\end{array}$ & & $\begin{array}{c}125 \\
(61,6)\end{array}$ & \\
\hline & $\begin{array}{l}\text { Respub- } \\
\text { likiné } \\
(N=1)\end{array}$ & $\begin{array}{c}99 \\
(42,7)\end{array}$ & & $\begin{array}{c}109 \\
(47,0)\end{array}$ & & $\begin{array}{c}117 \\
(50,4)\end{array}$ & & $\begin{array}{c}128 \\
(55,2)\end{array}$ & \\
\hline \multirow{4}{*}{$\begin{array}{c}\text { Parei- } \\
\text { gos }\end{array}$} & $\begin{array}{l}\text { Gydyto- } \\
\text { jas }\end{array}$ & $\begin{array}{c}35 \\
(29,2)^{* *}\end{array}$ & \multirow{4}{*}{$0,226^{* *}$} & $\begin{array}{c}35 \\
(29,2)^{* *}\end{array}$ & \multirow{4}{*}{$0,186^{\star *}$} & $\begin{array}{c}34 \\
(28,3)^{* *}\end{array}$ & \multirow{4}{*}{$0,22^{\text {** }}$} & $\begin{array}{c}57 \\
(47,5)\end{array}$ & \multirow{4}{*}{0,09} \\
\hline & $\begin{array}{l}\text { Slaugy- } \\
\text { tojas }\end{array}$ & $\begin{array}{c}176 \\
(46,3)^{* *}\end{array}$ & & $\begin{array}{c}185 \\
(48,7)^{* *}\end{array}$ & & $\begin{array}{c}216 \\
(56,8)\end{array}$ & & $\begin{array}{c}223 \\
(58,7)\end{array}$ & \\
\hline & $\begin{array}{l}\text { Slaugy- } \\
\text { tojo } \\
\text { padèjèja } \\
\text { s }\end{array}$ & $\begin{array}{c}50 \\
(62,5)^{\star *}\end{array}$ & & $\begin{array}{c}46 \\
(57,5)^{\star *}\end{array}$ & & $\begin{array}{c}45 \\
(56,3)\end{array}$ & & $\begin{array}{c}46 \\
(57,5)\end{array}$ & \\
\hline & $\begin{array}{l}\text { Kiti } \\
\text { specia- } \\
\text { listai }\end{array}$ & $\begin{array}{c}13 \\
(23,2)^{* *}\end{array}$ & & $\begin{array}{c}19 \\
(33,9)^{* *}\end{array}$ & & $\begin{array}{c}28 \\
(50,0)\end{array}$ & & $\begin{array}{c}28 \\
(50,0)\end{array}$ & \\
\hline \multirow{2}{*}{$\begin{array}{l}\text { Darbo } \\
\text { pobūdis }\end{array}$} & $\begin{array}{l}\text { Dirba } \\
\text { naktimis }\end{array}$ & $\begin{array}{c}193 \\
(44,3)\end{array}$ & \multirow[b]{2}{*}{0,035} & $\begin{array}{c}202 \\
(46,3)\end{array}$ & \multirow[b]{2}{*}{0,045} & $\begin{array}{c}237 \\
(54,4)^{*}\end{array}$ & \multirow{2}{*}{$0,105^{*}$} & $\begin{array}{c}264 \\
(60,6)\end{array}$ & \multirow[b]{2}{*}{$0,145^{* *}$} \\
\hline & $\begin{array}{l}\text { Nedirba } \\
\text { naktimis }\end{array}$ & $\begin{array}{c}81 \\
(40,5)\end{array}$ & & $\begin{array}{c}83 \\
(41,5)\end{array}$ & & $\begin{array}{c}86 \\
(43,0)^{*}\end{array}$ & & $\begin{array}{c}90 \\
(45,0) \\
* *\end{array}$ & \\
\hline \multicolumn{4}{|c|}{$05,{ }^{* *} p<0,001$} & & & & & & \\
\hline
\end{tabular}

2 lentelè. Sveikatos priežiūros specialistų požiūrio ị darbo aplinką pasiskirstymas pagal sociodemografinius duomenis ir jų sąsajos. 
paslydimo, kritimo esant nelygiam ar slidžiam paviršiui pavojų nurodė dažniau ( 25,7 proc.), negu nedirbantys naktimis (17,0 proc.). Jie taip pat dažniau nurode nepalankios biologinès darbo aplinkos šaltinius žmogaus skysčius (pvz., seiles, kraują, šlapimą ir kt.) ar jais užterštus paviršius/audinius $(54,1$ proc.) $(p<0,001)$.

Atlikus statistinę analizę nustatytos sąsajos tarp lyties, pareigų ir fizinès, ergonominès ir cheminès darbo aplinkos vertinimo bei naktinio darbo ir cheminès ir biologinès darbo aplinkos vertinimo (2 lentelè). Nustatytos sąsajos buvo silpnos arba vidutinès.

\section{Diskusija}

Tyrime siekėme nustatyti, kaip sveikatos priežiūros specialistai subjektyviai vertina savo darbo aplinką. Buvo nustatyti statistiškai reikšmingi skirtumai tarp lyčių, vertinant darbo aplinkos veiksnius. Šiuos duomenis pagrindžia ir Salin D. atliktame tyrime gauti rezultatai, kad moterys taip pat dažniau skundèsi prasta darbo aplinka [14]. Nors darbo aplinka turi būti ịrengta atsižvelgiant ị higienos normas ir kitus teisès aktus, užtikrinančius geras sąlygas darbuotojams, gauti tyrimo rezultatai parodo trūkumus darbo aplinkoje, kurioje dirba sveikatos priežiūros specialistai. Pasak Zhang LF, beveik pusè slaugytojų yra nepatenkinti savo darbu ir turi aukštą profesini perdegimą, o dalis jų ketina darbą palikti. Duomenys, kaip darbuotojai subjektyviai vertina darbo aplinką, gali padèti darbdaviams išlaikyti darbuotoją bei didinti jo produktyvumą [15]. Magid DJ su kolegomis JAV atliko tyrimą 65-iose ligoninèse, gauti rezultatai rodo, jog 62 proc. sveikatos priežiūros specialistų nepalankiai vertino savo fizinę darbo aplinką, nurode per mažas patalpas, iš kurių 24,8 proc. visada juto darbo erdvès trūkumą. Tyrime taip pat nustatyta, kad didesni kiekị pacientų turintys fizinę darbo aplinką vertina prasčiau [16]. Mahmood A. ir kt. prašè kelių ligoninių JAV sveikatos priežiūros specialistų nurodyti daugiausia nepatogumų sukeliančius darbo aplinkos veiksnius. Dažniausiai nurodomi buvo su darbo erdvès trūkumais susiję veiksniai, ergonominių baldų trūkumas, nepatogus patalpu išdèstymas [17]. Esama tyrimų, kur buvo nustatyta ir palankiai vertinama darbo aplinka, pvz., Haynes B. su kolegomis tyrè hemodializių skyriaus slaugytojų darbo aplinką Australijoje ir Naujojoje Zelandijoje bei nustate, kad darbo aplinką darbuotojai vertino gerai, tačiau vis tiek buvo galima išskirti sritis, kuriose darbdaviai galèjo pagerinti darbo aplinką [18]. Šiems rezultatams turejjo ịtakos ir pasirinktas tik vienas skyrius, o ne visa ligoninè, turinti daugiaprofilinius padalinius, todèl reikalingi tolimesni tyrimai ir kitose asmens sveikatos priežiūros įstaigose, siekiant tiksliau nustatyti, kuriuose skyriuose darbo aplinką reiktų gerinti.

Šio tyrimo metu buvo nustatyta, kad nemažai sveikatos priežiūros specialistų susiduria su nepalankia ergonomine darbo aplinka (44,8 proc.). Panašius rezultatus gavo ir darbuotojai, tyrę slaugytojų darbo aplinką vienoje iš Lietuvos ligoninių - vienas iš dažniausiai nurodytų rizikos veiksnių buvo pacientų kèlimas rankomis (33,9 proc.). Taip pat buvo nustatyta, kad slaugytojai, kurie kuo dažniau kèle pacientus rankomis, tuo prastesnį nurodè savo pasitenkinimą darbu [19]. Šiame tyrime nustatyti reikšmingi skirtumai tarp darbo aplinkos vertinimo ir naktinio darbo - dirbantys naktimis nurode dažniau susiduriantys su veiksniais, tai galima būtų sieti su Ferri P. su kolegomis atliktame tyrime gautais rezultatais, kur buvo nustatyta, jog dirbantys naktimis turi mažesnį pasitenkinimą darbu, prastesnę miego kokybę ir kiekybę, dažnesnị lètinị nuovargị ir psichologinius ar širdies ir kraujagyslių sutrikimus [20] bei patiria daugiau kaulų ir raumenų sistemos pažeidimų [21]. Darbdavius motyvuoti turètų ir darbo aplinkos gerinimo sąsajos su pacientų mirtingumu, nes buvo nustatyta, kad gera darbo aplinka padeda sumažinti išvengiamų mirčių ligoninèje skaičių [22]. Gauti tyrimo rezultatai parodo esamus trūkumus darbo aplinkoje bendrojo pobūdžio ligoninèse bei svariai pagrindžia darbo aplinkos gerinimo būtinybę.

\section{Išvados}

1. Beveik kas antras tyrimo dalyvis nurode nepalankius biologinès, cheminès, ergonominès ir fizinès darbo aplinkos veiksnius.

2. Moterys dažniau nepalankiai vertino fizinès, cheminès ir ergonominès darbo aplinkos veiksnius.

3. Nustatytos sąsajos tarp lyties, pareigu ir fizinès, ergonominès ir cheminès darbo aplinkos vertinimo. Taip pat nustatytos sąsajos tarp naktinio darbo ir cheminès ir biologinès darbo aplinkos vertinimo.

\section{Literatūra}

1. Mpofu C, Gupta TS, Hays R. The ethics of medical practitioner migration from low-resourced countries to the developed world: A call for action by health systems and individual doctors. Journal of Bioethical Inquiry 2016; 13(3):395-406.

https://doi.org/10.1007/s11673-016-9726-0

2. Aluttis C, Bishaw T, Frank MW. The workforce for health in a globalized context-global shortages and international migration. Global Health Action 2014;7(1):23611.

https://doi.org/10.3402/gha.v7.23611

3. Becker R, Teney C. Understanding high-skilled intra-European migration patterns: the case of European physicians in Germany. Journal of Ethnic and Migration Studies 2018;1-19.

https://doi.org/10.1080/1369183X.2018.1561249

4. Humphries N, Crowe S, Brugha R. Failing to retain a new generation of doctors: qualitative insights from a high-income 
country. BMC Health Services Research 2018;18(1):144. https://doi.org/10.1186/s12913-018-2927-y

5. Suliman M, Aljezawi M. Nurses' work environment: indicators of satisfaction. Journal of Nursing Management 2018;26(5):525-30.

https://doi.org/10.1111/jonm.12577

6. Perreira TA, Perrier L, Prokopy M. Hospital Physician Engagement. Medical Care 2018;56(12):969-75.

https://doi.org/10.1097/MLR.0000000000000983

7. Copanitsanou P, Fotos N, Brokalaki H. Effects of work environment on patient and nurse outcomes. British Journal of Nursing 2017;26(3):172-6.

https://doi.org/10.12968/bjon.2017.26.3.172

8. Cho H, Han K. Associations among nursing work environment and health promoting behaviors of nurses and nursing performance quality: A multilevel modeling approach. Journal of Nursing Scholarship 2018;50(4):403-10.

https://doi.org/10.1111/jnu.12390

9. Lohela-Karlsson M, Nybergh L, Jensen I. Perceived health and work-environment related problems and associated subjective production loss in an academic population. BMC Public Health 2018;18(1):257.

https://doi.org/10.1186/s12889-018-5154-x

10. Kartunavičiūtė J., Jankauskas R., Eičinaitė-Lingienė R., Matevičiūtė T. Lietuvos ir kitų Baltijos jūros regiono šalių profesinès sveikatos priežiūros tarnybų finansavimo pobūdis, žmogiškieji ištekliai ir profesinès sveikatos specialistų vykdomos funkcijos. Visuomenès sveikata, 2014;1(64):48-57.

11. Alhassan R K, Poku K A. Experiences of frontline nursing staff on workplace safety and occupational health hazards in two psychiatric hospitals in Ghana. BMC Public Health 2018;18(1), 701.

https://doi.org/10.1186/s12889-018-5620-5

12. Ndejjo R, Musinguzi G., Yu X., Buregyeya E., Musoke D., Wang J. S., ir kt. Occupational health hazards among healthcare workers in Kampala, Uganda. Journal of Environmental and Public Health 2015.

https://doi.org/10.1155/2015/913741

13. Gorman T, Dropkin J, Kamen J, Nimbalkar S, Zuckerman N, Lowe T, Szeinuk J, Milek D, Piligian G, Freund A. Controlling health hazards to hospital workers: a reference guide. NEW SOLUTIONS: A Journal of Environmental and Occupational Health Policy 2014;1-69.

https://doi.org/10.2190/NS.23.Suppl

14. Salin D. Risk factors of workplace bullying for men and women: The role of the psychosocial and physical work environment. Scandinavian Journal of Psychology 2015;56(1):69-77 https://doi.org/10.1111/sjop.12169

15. Zhang F, You M, Liu K, Zheng J, Fang B, Lu M, ir kt. The association of Chinese hospital work environment with nurse burnout, job satisfaction, and intention to leave. Nursing Ou- tlook 2014;62(2), 128-137.

https://doi.org/10.1016/j.outlook.2013.10.010

16. Magid DJ, Sullivan AF, Cleary PD, Rao SR, Gordon JA, Kaushal R, Guadagnoli E, Camargo Jr CA, Blumenthal D. The safety of emergency care systems: results of a survey of clinicians in 65 US emergency departments. Annals of Emergency Medicine 2009;53(6):715-23.

https://doi.org/10.1016/j.annemergmed.2008.10.007

17. Mahmood A, Chaudhury H, Valente M. Nurses' perceptions of how physical environment affects medication errors in acute care settings. Applied Nursing Research 2011;24(4):229-37. https://doi.org/10.1016/j.apnr.2009.08.005

18. Hayes B, Douglas C, Bonner A. Work environment, job satisfaction, stress and burnout among haemodialysis nurses. Journal of Nursing Management 2015;23(5), 588-598. https://doi.org/10.1111/jonm.12184

19. Jonikaitė R, Brasaitė I. Slaugytojų darbo aplinkos rizikos veiksnių ir pasitenkinimo gyvenimo kokybe sąsajos. Sveikatos mokslai, 2016;26(6):220-225

https://doi.org/10.5200/sm-hs.2016.120

20. Ferri P, Guadi M, Marcheselli L, Balduzzi S, Magnani D, Di Lorenzo R.. The impact of shift work on the psychological and physical health of nurses in a general hospital: a comparison between rotating night shifts and day shifts. Risk Management and Healthcare Policy 2016;9:203.

https://doi.org/10.2147/RMHP.S115326

21. Bazazan A, Dianat I, Bahrampour S, Talebian A, Zandi H, SharafkhanehA, Maleki-Ghahfarokhi A. Association of musculoskeletal disorders and workload with work schedule and job satisfaction among emergency nurses. International Emergency Nursing 2019.

https://doi.org/10.1016/j.ienj.2019.02.004

22. Cho E, Sloane DM, Kim EY, Kim S, Choi M, Yoo IY, Lee HS, Aiken LH. Effects of nurse staffing, work environments, and education on patient mortality: an observational study. International journal of nursing studies. 2015;52(2):535-42.

https://doi.org/10.1016/j.ijnurstu.2014.08.006

\section{HEALTHCARE SPECIALISTS' ATTITUDES TOWARDS THEIR WORK ENVIRONMENT FACTORS IN LITHUANIAN GENERAL HOSPITALS T.Steponkus, R.Ustinavičienė, G.Urbonas}

Keywords: healthcare specialists, work environment, general hospitals.

Summary

The working environment is widely explored in scientific literature, but there is a lack of research that investigates the attitude of work environment by the workers themselves, and in particular in the health care sector, which has specific working conditions.

Objective. The objective was to investigate healthcare specialists' attitudes towards their work environment factors in Lithuanian general hospitals. The methods of research. The Self-Repor- 
ted Work Environment Scale was used to estimate respondents' attitudes towards their working environment factors. Total of 636 health care specialists (doctors $(18.9 \%)$, nurses $(59.7 \%)$, nursing assistants $(12.6 \%)$, and other $(8.8 \%)$ specialists in 5 Lithuanian general hospitals participated in the study (response rate $85.7 \%$ ). Data analysis was performed using descriptive statistics, Chi-square $\left(\chi^{2}\right)$ and $\mathrm{z}$ criteria and Phi or Cramer's V correlation coefficients.

Results. According to respondents, biological (55.7\%), chemical (50.8\%), ergonomic (44.8\%) and physical (43.1\%) work environment factors are unfavorable in their work environment. Disinfectants (48.0\%), human fluids (47.5\%), and biomedical waste $(36.0 \%)$ were reported as the top most common hazards (out of a total of 23) that respondents had faced with at their workplace. Women confronted negative physical, chemical and ergonomic work environment factors more often than men $(p<0.05)$. Nurse assistants and nurses encountered more problems as compared to doctors and other specialists in ergonomic work environment factor $(p<0.05)$.

Conclusion. More than half of respondents are affected by chemical and biological factors in the work environment. Women are more often confronted with problems in the physical, chemical and ergonomic work environment. Links between gender, duties and physical, ergonomic and chemical work environment assessment was identified, also links between night work and chemical and biological work environment have been identified.

Correspondence to: tomas.steponkus@1smuni.1t

Gauta 2019-08-01 